Western North American Naturalist 68(1), (C) 2008, pp. 21-24

\title{
LATE-SEASONAL ACTIVITY AND DIET OF THE EVENING BAT (NYCTICEIUS HUMERALIS) IN NEBRASKA
}

\author{
Keith Geluso ${ }^{1,3}$, Jason P. Damm ${ }^{1}$, and Ernest W. Valdez ${ }^{2}$
}

\begin{abstract}
In North America, Nebraska represents part of the northwestern edge of the distribution for the evening bat (Nycticeius humeralis). To date, little information on this bat's natural history has been published from the state or from other parts of the Great Plains. Here we report on aspects of its natural history in Nebraska from 2 localities. In late summer and early autumn of 2006, we documented individuals farther west in Nebraska (Harlan County) than previously reported and determined that individuals fed mainly on Coleoptera and Hymenoptera. In 2006, evening bats appeared to migrate from Nebraska during late September-early October, and individuals were extremely fat, about $15 \mathrm{~g}$, prior to migration. Evening bats likely are more widespread and common in south central Nebraska than previously documented. On 6 October 2005, we reported on an individual from eastern Nebraska (Douglas County), which represents the latest seasonal record of $N$. humeralis from the state.
\end{abstract}

Key words: Nycticeius humeralis, evening bat, seasonal activity, diet, distribution, body mass, Nebraska.

The evening bat (Nycticeius humeralis) inhabits deciduous forests in the eastern United States and northeastern Mexico (Watkins 1972). In Nebraska, $N$. humeralis originally was known from 1 locality in the extreme eastern part of the state (Jones 1964). Recent captures demonstrate that it is widespread and relatively common across eastern Nebraska (Benedict et al. 2000, Benedict 2004, Geluso et al. 2004). Nebraska represents part of the northwestern edge of the distribution for $N$. humeralis, and to date, little information has been published on its natural history in the Great Plains. Herein, we report on aspects of its natural history during late summer and early autumn from 2 localities in Nebraska. We also include information on distribution, diet, habitat, seasonal activity, and body mass.

\section{Methods}

We captured most bats in 2.6- and 6.0-m mist nets (Avinet, Inc., Dryden, NY) along Prairie Dog Creek, Harlan County, Nebraska $\left(40^{\circ} 00.797^{\prime} \mathrm{N}, 099^{\circ} 21.874^{\prime} \mathrm{W}\right.$, NAD 1927$)$, but we also collected another bat by hand on 6 October 2005 outside a building at the University of Nebraska at Omaha, Douglas County. From August to October 2006, the creek in Harlan County was not flowing and contained isolated pools of water. Nets were set over water under the canopy of trees along the creek bed. Agricultural fields, including corn and alfalfa fields, surrounded the narrow band of trees immediately adjacent to the creek. Dominant trees included cottonwood (Populus deltoides), hackberry (Celtis occidentalis), American elm (Ulmus americana), and mulberry (Morus spp.).

After removal from nets and before their release, bats were held in small drinking cups for 1 hour to collect fecal pellets. We determined sex and measured body mass and forearm length of each individual, except for 2 individuals in August. Determination of juveniles was based on slightly tapered joints in the digits of the wings in contrast to the knobby joints of adults (Anthony 1988).

To examine diet of $N$. humeralis, we examined fecal pellets with a dissection microscope and followed techniques of Whitaker (1988). Number of fecal pellets examined varied from 1 to 7 for individuals, and all pellets from each bat were treated as 1 sample. We placed samples in a petri dish with $95 \%$ ethanol and pulled the pellets apart to observe small fragments of insects. We identified fragments to the lowest identifiable taxonomic group, usually to family. For each sample, we reported volume of each type of food as a percentage by visually estimating each food type. For the sum of all samples, we reported average percentage

\footnotetext{
${ }^{1}$ Department of Biology, University of Nebraska at Kearney, Kearney, NE 68849.

${ }^{2}$ United States Geological Survey, Arid Lands Field Station, Department of Biology, University of New Mexico, Albuquerque, NM 87131.

32E-mail: gelusok1@unk.edu
} 
TABLE 1. Diet of 14 evening bats (Nycticeius humeralis) based on analyses of fecal pellets. Bats were collected from Harlan County, Nebraska, in August (3 bats) and September (11 bats) 2006. Percentage volume represents averaged values for families of insects consumed, and summed totals for each order are placed in parentheses. Percentage frequency represents values for each family. For each order, overall percentage frequency is placed in parentheses.

\begin{tabular}{lcc}
\hline Food items & $\begin{array}{c}\text { Percentage } \\
\text { volume }\end{array}$ & $\begin{array}{c}\text { Percentage } \\
\text { frequency }\end{array}$ \\
\hline CoLEOPTERA & $(40.7)$ & $(100)$ \\
Scarabaeidae & 0.4 & 7.1 \\
Carabidae & 28.6 & 71.4 \\
Hydrophilidae & 5.1 & 21.4 \\
Chrysomelidae & 3.1 & 28.6 \\
Unidentified Coleoptera & 3.5 & 35.7 \\
HyMENOPTERA & $(23.3)$ & $(85.7)$ \\
HEMIPTERA & $(10.7)$ & $(92.3)$ \\
Corixidae & 2.3 & 57.1 \\
Lygaeidae & 8.3 & 71.4 \\
Unidentified Hemiptera & 0.1 & 7.1 \\
HoMOPTERA & $(7.2)$ & $(71.4)$ \\
Cicadellidae & 7.2 & 71.4 \\
LEPIDOPTERA & $(6.4)$ & $(28.6)$ \\
DIPTERA & $(0.6)$ & $(28.6)$ \\
UNIDENTIFIED INSECT & $(11.3)$ & $(71.4)$ \\
GRAND TOTAL & $(100.2)$ & \\
\hline
\end{tabular}

volume ([sum of sample volumes for a food type]/total volume $\times 100)$ and percentage frequency (total percentage of samples with that item).

Most bats captured in our study were released at the site of capture, but representative voucher specimens were deposited in the United States Geological Survey, Biological Survey Collection housed at the Museum of Southwestern Biology (MSB), University of New Mexico, Albuquerque. MSB numbers are given once in text for each voucher specimen.

\section{RESULTS}

In 2006, we captured 16 individuals of $N$. humeralis along Prairie Dog Creek in late summer and early autumn, along with 1 big brown bat (Eptesicus fuscus). On 26 August, we captured 4 female $N$. humeralis (2 adults, MSB 125026; 2 juveniles, MSB 125027). On this date, neither juvenile contained visible cartilage in the bones of the wings, but joints were slightly tapered. Body masses and forearm measurements of vouchers were $9.5 \mathrm{~g}$ and $37.0 \mathrm{~mm}$ for the adult and $9.5 \mathrm{~g}$ and $40.0 \mathrm{~mm}$ for the juvenile. On 29 September, we captured 12 additional individuals at the same site. All individuals were females (MSB 125028 and 125029), except for a single male (MSB 125030); ages were not determined on this date. Mean mass of females $1 \mathrm{~h}$ after capture was $15.1 \mathrm{~g}$ (range 13.9-16.5 g, $n=11$ ); the male had a mass of $11.9 \mathrm{~g}$. Mean forearm length for females was $38.5 \mathrm{~mm}$ (range 37-41 $\mathrm{mm}$ ), and the male measured $36.0 \mathrm{~mm}$. On 6 and 7 October 2006, we returned to this site and failed to capture any additional bats.

We discovered remains of 7 families of insects belonging to 6 orders (Table 1) in fecal pellets of 14 individuals. The major food items were Coleoptera (beetles) and Hymenoptera (wasps and ants), composing $40.7 \%$ and $23.3 \%$ of the total volume, respectively. On 6 October 2005, the male $N$. humeralis captured in Omaha, Douglas County (MSB 125031), had a body mass of $12.4 \mathrm{~g}$ and a forearm measurement of $37.0 \mathrm{~mm}$.

\section{Discussion \\ Distribution}

In recent years, the distribution of $N$. humeralis has expanded westward and northward in the Great Plains (Benedict et al. 2000, Sparks and Choate 1995, 2000, Lane et al. 2003, Benedict 2004). Westward movement of $N$. humeralis likely has followed riparian corridors with substantial patches of woodlands. For example, Sparks and Choate (1995, 2000) suggested that individuals recently reported from central Kansas were absent in the region in recent historic time because of a lack of suitable wooded habitats. In our study, we captured 16 individuals along Prairie Dog Creek, a tributary of the Republican River. Both watercourses currently contain continuous bands of riparian woodlands surrounded mainly by agricultural fields and upland prairies. Our records represent a $75-\mathrm{km}$ range extension from the previous westernmost locality in Webster County (Czaplewski et al. 1979). Additional netting along the Republican River and its tributaries likely will show that this species occurs farther westward in the state.

\section{Diet}

The diet of $N$. humeralis has been examined in eastern parts of its range in Indiana (Whitaker and Clem 1992, Whitaker 2004), Illinois (Feldhamer et al. 1995), and South Carolina (Carter et al. 2004). To date, there are no data regarding diet from the Great Plains. 
Evening bats from Nebraska fed upon various orders of insects (Table 1), as reported from other states. Evening bats apparently have been classified as beetle strategists (see Sparks and Choate 2000), but they also regularly feed upon other groups of insects such as moths (Lepidoptera), leaf hoppers (Homoptera: Cicadellidae), true bugs (Hemiptera), and wasps and ants (Hymenoptera), depending on season and location (Whitaker and Clem 1992, Carter et al. 2004, Whitaker 2004; Table 1).

\section{Seasonal Activity}

Previous dates of activity for evening bats in Nebraska were from 9 May to 1 October (Benedict 2004). The capture of a bat on 6 October 2005 in Douglas County extends the late-seasonal date of activity of $N$. humeralis in Nebraska. In 2006, evening bats appeared to migrate from Prairie Dog Creek during late September-early October. On 6 and 7 October 2006, we attempted to capture additional individuals at this site only a week after we captured 12 individuals. In October, temperatures still were warm, and many night-flying insects were along the creek. We did not observe any bats flying along the creek during those nights and suspect that evening bats had migrated from the area.

Our dates of late-seasonal activity are similar to dates when other eastern populations vacate summer roosts to migrate. Watkins and Shump (1981) reported that all N. humeralis vacated a maternity roost in northern Missouri by 17 September; Watkins (1969) reported the departure of bats from maternity roosts in Missouri by 12 October, Humphrey and Cope (1968) reported that no bats were found in a roost in Indiana after 21 September; Smith and Parmalee (1954) reported that a large colony in an attic in Illinois left between 26 August and 1 November; and Clem (1992) reported that bats were last observed in a maternity roost in Indiana on 3 November.

\section{Body Mass}

In northern parts of its range, the evening bat is assumed to be migratory (Humphrey and Cope 1968, Watkins 1972), but see Boyles and Robbins (2006). Before seasonal movements in autumn, individuals amass subcutaneous deposits of fat. Baker et al. (1968) reported that $N$. humeralis from Georgia had body masses up to $14.7 \mathrm{~g}$, with the highest lev- els of fat in October. Body masses of our individuals represented individuals that had obvious fat deposits and also individuals that had eaten before capture. Mean body mass of females $(15.1 \mathrm{~g})$ captured on 29 September in Nebraska represents some of the heaviest body masses reported for this species (Kunz 1965, Mumford 1969, Bee et al. 1981). Body masses in our study likely represent those just before migratory movements from Nebraska.

In winter, $N$. humeralis has been reported from various locations in the southeastern United States, but its winter range is not well defined (Boyles and Robbins 2006). Although evening bats have been shown to migrate (Humphrey and Cope 1968, Watkins 1969), both sexes are resident throughout the year as far north as southwestern Missouri (Boyles and Robbins 2006). To date, little is known about winter habits of $N$. humeralis, but individuals are known to roost in trees and underground in winter (Boyles et al. 2005, Boyles and Robbins 2006). Much information remains to be gathered on movements and other aspects of natural history for this species throughout its entire distribution, especially from autumn to spring.

\section{ACKNOWLEDGMENTS}

We thank P.M. Cryan, K.N. Geluso, J.O. Whitaker, Jr., J.A. Williams, and an anonymous reviewer for helpful comments on earlier versions of the manuscript; C.A. Ramotnik (United States Geological Survey, Biological Survey Collection, MSB, University of New Mexico, Albuquerque) for her assistance in museum matters associated with this research; and D.J. Mack and K.N. Geluso for alerting us to the $N$. humeralis from Douglas County.

\section{Literature Cited}

Anthony, E.L.P. 1988. Age determination. Pages 47-57 in T.H. Kunz, editor, Ecological and behavioral methods for the study of bats. Smithsonian Institution Press, Washington, DC.

Baker, W.W., S.G. Marshall, and V.B. Baker. 1968. Autumn fat deposition in the evening bat (Nycticeius humeralis). Journal of Mammalogy 49:314-317.

Bee, J.W., G.E. Glass, R.S. Hoffmann, and R.R. PatterSON. 1981. Mammals in Kansas. University of Kansas Museum of Natural History, Public Education Series 7:1-300.

BENEDICT, R.A. 2004. Reproductive activity and distribution of bats in Nebraska. Western North American Naturalist 64:231-248. 
Benedict, R.A., H.H. Genoways, and P.W. Freeman. 2000. Shifting distributional patterns of mammals in Nebraska. Transactions of the Nebraska Academy of Sciences 26:55-84.

Boyles, J.G., B.M. Mormann, and L.W. Robbins. 2005. Use of an underground winter roost by a male evening bat (Nycticeius humeralis). Southeastern Naturalist 4:375-377.

Boyles, J.G., AND L.W. RobBins. 2006. Characteristics of summer and winter roost trees used by evening bats (Nycticeius humeralis) in southwestern Missouri. American Midland Naturalist 155:210-220.

Carter, T.C., M.A. Menzel, B.R. Chapman, and K.V. Miller. 2004. Partitioning of food resources by syntopic eastern red (Lasiurus borealis), Seminole ( $L$. seminolus), and evening (Nycticeius humeralis) bats. American Midland Naturalist 151:186-191.

Clem, P.D. 1992. Seasonal population variation and emergence patterns in the evening bat, Nycticeius humeralis, at a west-central Indiana colony. Proceedings of the Indiana Academy of Science 101:33-44.

Czaplewski, N.J., J.P. Farney, J.K. Jones, Jr., and J.D. Druecker. 1979. Synopsis of bats of Nebraska Occasional Papers, Museum of Texas Tech University $61: 1-24$.

Feldhamer, G.A., J.O. Whitaker, JR., J.K. Krejca, and S. TAYLOR. 1995. Food of the evening bat (Nycticeius humeralis) and red bat (Lasiurus borealis) from southern Illinois. Transactions of the Illinois Academy of Science 88:139-143.

Geluso, K.N., R.A. Benedict, And F.L. Kock. 2004. Seasonal activity and reproduction in bats of east-central Nebraska. Transactions of the Nebraska Academy of Sciences 29:33-44.

Humphrey, S.R., And J.R. Cope. 1968. Records of migration of the evening bat, Nycticeius humeralis. Journal of Mammalogy 49:329.

JoneS, J.K., JR. 1964. Distribution and taxonomy of mammals of Nebraska. Publications of the Museum of Natural History, University of Kansas 16:1-356.

Lane, J.E., C.L. Buck, and R.M. Brigham. 2003. The bat fauna of southeastern South Dakota. Prairie Naturalist 35:247-256.
KunZ, T.H. 1965. Notes on some Nebraskan bats. Transactions of the Kansas Academy of Science 68:201-203.

Mumford, R.E. 1969. Distribution of the mammals of Indiana. Monograph of the Indiana Academy of Science 1:1-114.

Smith, P.W., and P.W. ParmaleE. 1954. Notes on distribution and habits of some bats from Illinois. Transactions of the Kansas Academy of Science 57:200-205.

Sparks, D.W., and J.R. ChOate. 1995. New distribution records of mammals from Kansas. Prairie Naturalist 27:185-192.

2000. Distribution, natural history, conservation status, and biogeography of bats in Kansas. Pages 173-228 in J.R. Choate, editor, Reflections of a naturalist: papers honoring Professor Eugene D. Fleharty. Fort Hays Studies, Special Issue 1.

Watkins, L.C. 1969. Observations on the distribution and natural history of the evening bat (Nycticeius humeralis) in northwestern Missouri and adjacent Iowa. Transactions of the Kansas Academy of Science 72: 330-336.

1972. Nycticeius humeralis. Mammalian Species 23:1-4.

WATKINS, L.C., AND K.A. Shump, JR. 1981. Behavior of the evening bat Nycticeius humeralis at a nursery roost. American Midland Naturalist 105:258-268.

Whitaker, J.O., JR. 1988. Food habits analysis of insectivorous bats. Pages 171-190 in T.H. Kunz, editor, Ecological and behavioral methods for the study of bats. Smithsonian Institution Press, Washington, DC. 2004. Prey selection in a temperate zone insectivorous bat community. Journal of Mammalogy $85: 460-469$

Whitaker, J.O., JR., AND P. Clem. 1992. Food of the evening bat Nycticeius humeralis from Indiana. American Midland Naturalist 127:211-214.

Received 1 March 2007

Accepted 27 August 2007 